\title{
Coming Medical Meetings
}

2.-3. Juni 1972: $\quad$ 18. Tagung der Nordrhein-Westfälischen Gesellschaft fur Urologie in Essen

1. Das Blasenkarzinom. 2. Die Prostatitis.

Schriftführer: Dr. E. Simons, Chefarzt der Urol. Abteilung, Eli-sabethen-Krankenhaus, Rheydt (BRD).

4.-7. Juni 1972: $\quad$ Internationaler Kongress fur Kryochirurgie, Wien

Sekretariat: Univ.-Doz. Dr. H. Haschek, Alserstrasse 4, A-1090 Wien (Österreich), June 8-10, 1972: IX. Congress of the European Dialysis and Transplant Association (E. D. T. A.), Firenze

Secretary of the Congress: V. E. Andreucci, M.D., II Clinica Medica Università, 1-43100 Parma (Italy).

9.-11. Juni 1972: $\quad$ Kongress der Polnischen Gesellschaft für Urologie, in Lublin Auskunft: Prof. Dr. Antoni Szczerbo, Urologische Klinik, Zarzad Glowny Jaczewskiego 8, Lublin (Polen).

14.-16. Juni 1972: $\quad$ Symposium der Urologen, in Bratislava Auskunft: Dr. med. Horniak, Urologische Klinik, Kramárel Bratislava (CSSR).

June 18-22, 1972: Congress of the American College of Surgeons, in San Francisco, Calif.

Informations: Ernest D. Howard, M.D., 535 North Dearban Street, Chicago, III. 60610 (USA). July 5-8, 1972: $\quad$ 28th Annual General Meeting of the British Association of Urological Surgeons, in Newcastle-upon-Tyne

'The Management of Internal and External Urinary Fistula.'

President: J. D. Fergusson, M.D., The Royal College of Surgeons of England, Lincoln's Inn Fields, London WC 2A 3 PN (England).

October 23-28, 1972: International Atomic Energy Agency Symposium, at Monaco Medical Radioisotope Scintigraphy.

Scientific Secretaries: Dr. E. H. Belcher and Dr. T. Nagay, Medical Applications Section, Kärntner Ring 11, P.O.Box 590, A-101/ Vienna (Austria). 